\title{
Ataxia-oculomotor apraxia type 1
}

INSERM

\section{Source}

INSERM. (1999). Orphanet: an online rare disease and orphan drug data base. Ataxiaoculomotor apraxia type 1. ORPHA:1168

Ataxia with oculomotor apraxia type 1 (AOA1) is a rare autosomal recessive cerebellar ataxia (ARCA; see this term), characterized by progressive cerebellar ataxia associated with oculomotor apraxia, severe neuropathy, and hypoalbuminemia. 